\title{
Self-perceived health and clinical characteristics in young adult students from the brazilian northeast
}

\author{
AUTOPERCEPÇÃO DE SAÚDE E CARACTERÍSTICAS CLÍNICAS EM ADULTOS JOVENS \\ ESCOLARES DE UM INTERIOR DO NORDESTE BRASILEIRO
}

\begin{abstract}
AUTOPERCEPCIÓN DE SALUD Y CARACTERÍSTICAS CLÍNICAS EN ESTUDIANTES JÓVENES ADULTOS DE UNA PARTE DEL INTERIOR DEL NORDESTE BRASILEÑO
\end{abstract}

\section{Thereza Maria Magalhães Moreira ${ }^{1}$, Jênifa Cavalcante dos Santos Santiago², Gizelton Pereira Alencar ${ }^{3}$}

\begin{abstract}
Objective: To analyze the association between socioeconomic situation, clinical characteristics referred and the family history of cardiovascular disease, with the Self-perceived health of young adults education and their implications for clinical characteristics observed. Method: Analytical study conducted with 501 young adults who are students in countryside city in the Brazilian Northeast. We used binary logistic regression. Results: The final model explained $83.3 \%$ of the self-perceived positive health, confirming the association of Selfperceived health with male, residence in the community, have excellent/very good lifestyle and does not have or do not know that there are cases of stroke in the family. Conclusion: Health perception was often optimistic, being important to identify devices to be worked closer to their perception of their actual health condition, increasing the effectiveness of health promotion activities undertaken by professionals.
\end{abstract}

\section{DESCRIPTORS}

Cardiovascular diseases

Risk factors

Young adult

Students

Health promotion

Public health nursing

\section{RESUMO}

Objetivo: Analisar a associação entre a situação socioeconômica, as características clínicas referidas e o histórico de doença cardiovascular familiar, com a Autopercepção da saúde de escolares adultos jovens e suas implicações nas características clínicas observadas. Método: Estudo analítico desenvolvido com 501 adultos jovens escolares de um interior do Nordeste brasileiro. Utilizou-se a regressão logística binária. Resultados: O modelo final explicou $83,3 \%$ da autopercepção de saúde positiva, confirmando associação da Autopercepção de saúde com sexo masculino, moradia em comunidade, ter estilo de vida excelente/ muito bom e não ter ou não saber que tem casos de AVC na família. Conclusão: A percepção de saúde muitas vezes foi otimista, necessitando-se identificar os dispositivos a serem trabalhados para aproximar a sua percepção de sua real condição de saúde, aumentando a eficácia das ações de promoção da saúde desenvolvidas pelos profissionais.

\author{
DESCRITORES \\ Doenças cardiovasculares \\ Fatores de risco \\ Adulto jovem \\ Estudantes \\ Promoção da saúde \\ Enfermagem em saúde pública
}

\section{RESUMEN}

Objetivo: Analizar la asociación entre la situación socioeconómica, los rasgos clínicos mencionados y los antecedentes de enfermedad cardiovascular familiar, con la autopercepción de la salud de estudiantes adultos jóvenes y sus implicaciones en las características clínicas observadas. Método: Estudio analítico desarrollado con 501 estudiantes jóvenes adultos de una parte del interior del Nordeste brasileño. Se utilizó la regresión logística binaria. Resultados: El modelo final explicó el 83,3\% de la autopercepción de salud positiva, confirmando la asociación de la Autopercepción de salud con sexo masculino, vivienda en comunidad, tener estilo de vida excelente/ muy bueno y no tener o no saber que hay casos de AVC en la familia. Conclusión: La percepción de salud a menudo fue optimista, necesitándose identificar los dispositivos que se deben trabajar para acercar la percepción de su real condición de salud, incrementando la efectividad de las acciones de promoción de la salud desarrolladas por los profesionales.

\section{DESCRIPTORES}

Enfermedades cardiovasculares

Factores de riesgo

Adulto joven

Estudiantes

Promoción de la salud

Enfermería en salud pública

${ }^{1}$ Professor of Clinical Nursing Health Care Program and the Community Health Program, State University of Ceará, Fortaleza, CE, Brazil. ${ }^{2}$ PhD Student, Clinical Nursing Health Care Program, Federal University of Ceará, Fortaleza, CE, Brazil. ${ }^{3}$ Statistician, Associate professor, Department of Epidemiology, School of Public Health, University of São Paulo, São Paulo, SP, Brazil. 


\section{INTRODUCTION}

The literature provides strong evidence regarding cardiovascular diseases (CVD), which is manifested in adulthood as a result from a complex interaction between a variety of risk factors that may originate in childhood and adolescence ${ }^{(1-2)}$. Early detection of the presence of risk factors in youth enables the planning and implementation of preventive intervention programs aimed at reducing the likelihood of manifestation of CVD in the future.

The aggregation of these factors related to time leads to the development of cardiovascular changes even in the population of young adults (20-24 years), fact proven in some studies ${ }^{(3-4)}$. In addition, the World Health Organization (WHO) and the Pan American Health Organization (PAHO) $)^{(5)}$ estimate that exposure to cardiovascular risk factors (CVRF) will lead to 36 million premature deaths by 2015 , with special attention to developing countries.

Primarily prevention, early detection and control of the CVRF is the hope to prevent/diminish the progression of CVD and its complications, subsidizing secondary prevention $^{(3)}$. The literature, however, is scarce regarding the researches about health of young adults. In order to better prevent these and other diseases, it would be necessary to know the self-perceived health of that population and its influencing factors, which would facilitate the approach of health education actions.

The Self-perception of health, or how the person perceives their health can be measured by a simple question with answer choice on four scales (excellent, good, regular and poor). Added to the advantage of applicability, this strategy to collect information about health may be useful to complement data derived from the diagnostic phase in programs for health promotion. The association of perceived health status with mortality and health indicators have been reported for different populations ${ }^{(6)}$.

Experience for over 15 years in dealing with chronic patients from 40 years old has shown that even in the presence of negative self-perceived health, people do not change their lifestyle because it is already established in the individual, being rare and complex the processes to reverse this situation. However, what about young adults? Would a positive self-perception of health be related to a positive lifestyle? Facing this reality, a statistical model of association of self-perception of health in young adult who were students was developed.

Relationships between the study variables were assumed (Socioeconomic Situation-SES, Clinical Characteristics Referred - CC-r and Family History of Cardiovascular Disease-CVD-f) and Self-perception of Health as well as its association with clinical characteristics observed CC-o $\{[$ (Presence of Elevated blood pressure$\mathrm{SBP}+$ and $\mathrm{DBP}+$ )], [Tests (Hyperglycemia-Gluct and Hypercholesterolemia-Col+)]; [Body Mass Index and Waist Circumference (Overweight-Ov+ and Obesity-Ob+)]\}. The results generated will subsidize health promotion with the clientele.

The aim of the study was to analyze the association between Socioeconomic Status (SES), Clinical Characteristics Referred (CC-r) and Family History of Cardiovascular Disease (CVD-f) with Self-perceived Health of young adult students who are students from the countryside of the Northeast of Brazil and their implications for Clinical Characteristics Observed (CC-o).

\section{METHOD}

This is an analytical, quantitative study, developed with student who are young adults (20-24 years old) of a countryside city in the state of Ceará with data collection conducted between December 2011 and May of 2012.

The location of the research comprised a city located in the Metropolitan Region of Fortaleza, with 206,000 inhabitants $^{(7)}$. It is an urban area with lots of industries, which has the second largest budget revenues of Ceará and 93\% coverage of the Family Health Strategy. This choice was due to the fact that this is a city with a representative population for statistical data and awarded nationally in the area of health care of adolescents and young adults, in addition to the health program of the school enrolled. The region has 16 state secondary schools and 43 municipal Education with Youth and Adults (EJA), which compromised our participants.

The sample for infinite population had a prevalence of $50 \%$ for positive self-perceived health, the lack of prevalence studies in the municipality with this population, and error of $5 \%{ }^{(8)}$. We estimated the sample in 384 , adding $30 \%$ to the total for any withdrawals or missing, totaling 500 people, with 501 participants for convenience and stratified by school. The criterion for inclusion in the sample was to be between 20 and 24 years old and be enrolled in the schools studied. And exclusion, the absence in the days of data collection.

Concerning data collection, it was thought of in three phases: 1) awareness and selection of participants per school; 2) a questionnaire was used to collect data related to the following variables: Socioeconomic SituationSES, Clinical Characteristics Referred CC-r, Family History of Cardiovascular Disease-CVD-f and Self-perception Health; and 3) laboratory tests were conducted to obtain data on Clinical Characteristics Observed CC-o- $\{[$ High Blood Pressure- $\mathrm{SBP}+$ e $\mathrm{DBP}+$ )], [biochemical tests (Hyperglycemia-Gluc+ and Hipercolestolremia-Col+)]; [Body Mass Index and Waist Circumference (Overweight-Ov+ and Obesity-Ob+]\}.
Self-perceived health and clinical characteristics in young adult students from the brazilian northeast Moreira TMM, Santiago JCS, Alencar GP 
In the first phase, the thematic and objectives of the study were presented to the Department of Education and the County Health Department, followed by school principals. Once we had the lists with the names and ages of students per class and school, schools were visited and each classroom with students in the desired age range. In each room, the research and its purpose were explained, nominating potential candidates for the sample. Those who agreed to participate in the study were removed to a separate study room. In this room, the consent form - CF was signed, and the research was explained again and, after that they fulfilled the questionnaire (phase 2). Once they had finished answering the questionnaire, students were directed to another room to check weight, height, blood pressure, glucose and cholesterol tests (phase 3 ). The nonacceptance to participate and/or abandonment was followed by the replacement of the student, adopting the same criteria.

Therefore, the second phase of data collection included the completion of a questionnaire: 1) Socioeconomic Situation-SES: income, parental education and if live in a slum area; 2) Clinical Characteristics referred-CC$r$ : whether the person has hypertension and/or diabetes; and 3) Presence of Family History of Cardiovascular Disease (CVD-f): cases of hypertension, heart disease, stroke, diabetes or hypercholesterolemia in the family. The Fantastic Lifestyle instrument was also applied to investigate Self-perception of health, measured by a question with answer choice on a scale of four options (excellent, good, regular and poor).

In the third phase of data collection, the biochemical indicators of blood glucose, total cholesterol, HDL were evaluated after capillary blood collection, considering aseptic technique and use of personal protective equipment (PPE) and proper disposal of sharps.

Presence of elevated blood pressure (BP+) was checked on blood pressure measurement. This was recorded in two subsequent moments in the same day, because it is not a diagnosis. The method was indirect, auscultation technique and aneroid sphygmomanometer calibrated by inmetro. The technique of verification and evaluation of the pressure figures followed the recommended protocol by the Brazilian Society of Cardiology in the VI Brazilian Guidelines on Hypertension ${ }^{(9)}$.

The postprandial blood glucose was verified after at least two hours of feeding, as fasting plasma glucose was infeasible since data collection was performed at night. Obesity (Ob)/Overweight was verified based on body mass index, calculated by body weight in kilograms divided by the square of height in meters, and waist circumference.

Regarding anthropometric measurements, for height, the examined participants remained standing, with feet together and extended along the body and arms without shoes, facing the examiner and using the metal tape measure of the anthropometric scale. Measurement of Abdominal Circumference (AC) was performed with a tape measure and clothes away, locating the tape at the midpoint between the anterior superior iliac crest and the last rib, and the values considered normal were $88 \mathrm{~cm}$ for women and $102 \mathrm{~cm}$ for men ${ }^{(9)}$. Weight was measured on an anthropometric scale for adults, calibrated with the participant standing and arms close to the body with the lowest possible weight clothes and without shoes.

In the analysis, the $\mathrm{X}^{2}$ test was initially used for categorical predictor variables, crosstabed with Self-perception of health, followed by binary logistic regression.

This project was approved by the Ethics Committee in Research of the State University of Ceará (UECE), under case number 11044795-6, in compliance with Resolution 466 of $2012^{(10)}$. The project was funded by the National Council for Scientific and Technological Development-CNPq.

\section{RESULTS}

When thinking about the best way to take care of a customer, it is relevant to know their characteristics, essential to observe the vulnerabilities to which they are exposed.

Regarding self-perceived health, more than half (57.9\%) considered it good $(11.0 \%)$ or very good $(46.9 \%)$, indicating positive self-perception of health. However, $42.1 \%$ showed a negative perception of health, of which $36.9 \%$ conceptualized it as regular and $5.2 \%$ as poor. Thus, self-perceived health was positive for 290 students (57.9\%) and negative for 211 (42.1\%).

Univariate analysis of socioeconomic situation (SES) of customers revealed that almost half of participants was 20 years old $(48.6 \%)$ and just over half were female $(50.9 \%)$. Most of them were single (76.2\%) and had no children (76.6\%), while $110(21.9 \%)$ had 1 to 4 children, with often have a child $(73,14.6 \%)$. Just over a third of them selfperceived themselves as being of mixed race (36.7\%). It was also observed that $75.8 \%$ had a family income of up to two minimum wages and only $7.8 \%$ said they live in slums. With regard to education, it was predominant the second or third year of high school $(32.1 \%$ and $38.1 \%$, respectively). Finally, on family education, more than three quarters of their parents (39.2\%) had elementary education and more than a quarter of mothers $(21.0 \%)$ had secondary education.

Clinical Characteristics referred (CC-r), despite the few cases of hypertension and DM, more than a third did not know if had hypertension and $43.1 \%$ did not 
know if they had diabetes. In the Presence of Family Cardiovascular Disease (CVD-f), univariate analysis revealed that of the total, $303(60.5 \%)$ reported cases of hypertension in the family, $237(47.3 \%)$ of diabetes, $187(37,3 \%)$ of heart disease, $91(18.2 \%)$ of stroke (CVA) and $49(9.8 \%)$ cases of acute myocardial infarction. Furthermore, although not cardiovascular disease, but for their contribution to this problem, they were asked about obesity and dyslipidemia in their family, being reported 145 (28.9\%) and 175 (34.9\%) cases, respectively. The most frequently reported kinships were fathers, brothers, uncles and grandparents.
About the Clinical Characteristics Observed (CC-o), univariate analysis revealed that, when examined, participants showed almost all SBP and DBP to be normal (93\% and $93.4 \%$, respectively). Regarding BMI, more than a third of them were overweight/obese (35.7\%). Of these, 129 (25.7\%) were overweight and 50 (9.98\%) obese. From obese, 35 (7\%) had grade I obesity, eleven (2.2\%) grade II and four (0.8\%) grade III or morbid obesity. Regarding glucose, almost all were within normal limits and only 17 (3.4\%) presented alterations (>139 $\mathrm{mg} / \mathrm{dL}$ ). With regard to total cholesterol, almost $90 \%$ were within the threshold considered normal $(<200 \mathrm{mg} / \mathrm{dL})$ and $43(8.6 \%)$ had changes.

Table 1 - Sociodemografic situation (SES) and Self-perceived Health - Maracanaú, CE, Brazil, 2012

\begin{tabular}{|c|c|c|c|c|}
\hline \multirow{2}{*}{ Predictive variables } & \multicolumn{2}{|c|}{$\begin{array}{c}\text { Outcome: } \\
\text { Self-perceived health }\end{array}$} & \multirow{2}{*}{ Total } & \multirow{2}{*}{$\mathbf{p}$} \\
\hline & Positive & Negative & & \\
\hline Gender $(n=499)$ & & & & $<0,001 *$ \\
\hline Male & 163 & 81 & 244 & \\
\hline Female & 125 & 130 & 255 & \\
\hline Marital status $(n=497)$ & & & & $0,026^{*}$ \\
\hline Single/Separated & 235 & 153 & 388 & \\
\hline Married/Stable union & 53 & 56 & 109 & \\
\hline Children $(n=492)$ & & & & $0,181^{*}$ \\
\hline Yes & 56 & 52 & 108 & \\
\hline No & 228 & 156 & 384 & \\
\hline Paid job $(n=482)$ & & & & 0,68 \\
\hline Yes & 177 & 127 & 304 & \\
\hline No & 103 & 75 & 178 & \\
\hline Family income/per month $(n=499)$ & & & & 0,907 \\
\hline Up to two minimum wages* (MW) & 232 & 168 & 400 & \\
\hline More than two MW & 56 & 43 & 99 & \\
\hline Father's education $(n=454)$ & & & & 0,397 \\
\hline Up to elementary education & 181 & 144 & 325 & \\
\hline High school & 62 & 42 & 104 & \\
\hline College education & 17 & 8 & 25 & \\
\hline Mother's education $(n=492)$ & & & & 0,636 \\
\hline Up to elementary education & 205 & 157 & 362 & \\
\hline High school & 65 & 40 & 105 & \\
\hline College education & 16 & 9 & 25 & \\
\hline Live in a slum $(n=501)$ & & & & $0,060^{*}$ \\
\hline Yes & 17 & 22 & 39 & \\
\hline No & 273 & 189 & 462 & \\
\hline
\end{tabular}

Below, we will start the analysis of the Self-perceived health as the outcome, taking as a predictor, initially, the SES-socioeconomic situation of study participants.

Considering the initial standard of 0.2 for statistical significance, statistical association with Self-perceived health in the item in Sociodemographic situation (SSE) was presented in the variables gender $(p<0.001)$, marital status $(p=0.026)$, children $(n=0,181)$ and not living in slum (0.060).

In the table below, we verified the association of the outcome Self-perceived Health with Clinical Characteristics Referred (CC-r).
Self-perceived health and clinical characteristics in young adult students from the brazilian northeast Moreira TMM, Santiago JCS, Alencar GP 
Table 2 - Clinical Characteristics Referred (CC-r) and Self-perceived Health - Maracanaú, CE, Brazil, 2012

\begin{tabular}{|c|c|c|c|c|}
\hline \multirow{2}{*}{ Predictive variables } & \multicolumn{2}{|c|}{$\begin{array}{l}\text { Outcome: } \\
\text { Self-perceived health }\end{array}$} & \multirow[t]{2}{*}{ Total } & \multirow{2}{*}{$\mathbf{p}$} \\
\hline & Positive $=1$ & Negative $=2$ & & \\
\hline Do you have hypertension? $(n=501)$ & & & & $0,041^{*}$ \\
\hline Yes & 3 & 5 & 8 & \\
\hline No & 194 & 119 & 313 & \\
\hline I don't know & 93 & 87 & 180 & \\
\hline Do you have diabetes? $(n=499)$ & & & & $0,024 *$ \\
\hline Yes & 4 & 1 & 5 & \\
\hline No & 171 & 103 & 274 & \\
\hline I don't know & 113 & 107 & 220 & \\
\hline Have you done or are you doing treatments for systemic hypertension? $(n=501)$ & & & & 0,975 \\
\hline Yes & 7 & 5 & 12 & \\
\hline No & 283 & 206 & 489 & \\
\hline Have you done or are you doing treatments for DM? $(n=501)$ & & & & 0,661 \\
\hline Yes & 4 & 2 & 6 & \\
\hline No & 286 & 209 & 495 & \\
\hline Has any health professional told you have systemic hypertension? $(n=501)$ & & & & $0,014 *$ \\
\hline Yes & 2 & 8 & 10 & \\
\hline No & 288 & 203 & 491 & \\
\hline Has any health professional told you have dyslipidemia? $(n=501)$ & & & & $0,024 *$ \\
\hline Yes & 4 & 10 & 14 & \\
\hline No & 286 & 201 & 487 & \\
\hline Has any health professional told you have hyperglycemia/diabetes? $(\mathrm{n}=501)$ & & & & $0,024 *$ \\
\hline Yes & 4 & 10 & 14 & \\
\hline No & 286 & 201 & 487 & \\
\hline Has any health professional told you are overweight/obese? $(n=501)$ & & & & $0,011^{*}$ \\
\hline Yes & 21 & 30 & 51 & \\
\hline No & 269 & 181 & 450 & \\
\hline Fantastic LifeStyle (FLS) $(n=364)$ & & & & $0,005^{*}$ \\
\hline Excellent and Very good & 23 & 31 & 54 & \\
\hline Good & 93 & 77 & 170 & \\
\hline Regular and need improvement & 94 & 46 & 140 & \\
\hline
\end{tabular}

In Table 2, we showed statistical association with Selfperceived health (statistical significance greater than 0.2 ) the predictor variables have hypertension $(p=0.041)$ and/ or diabetes $(p=0.024)$, if a health professional has told the participant had systemic hypertension $(p=0.014)$, dyslipidemia $(p=0.024)$, hyperglycemia/diabetes $(p=0.024)$ or that the participant is overweight/obese $(p=0.011)$, and lifestyle $(p=0.005)$.
Considering the Family History of Cardiovascular Disease (CVD-f) and its association with Self-perceived Health.

Table 3 indicates that the item Cardiovascular Disease in the Family (CVD-f) is statistically associated with Self-perceived health variables: Hypertension in the family $(p=0.083)$, diabetes $(p=0.089)$, heart disease $(p=0.021)$, stroke $(p<0.001)$ and heart attack $(p=0.001)$. The overweight/obese mothers had approximately $5 \%(p=0.054)$ and was kept in the model.

Table 3 - Family History of Cardiovascular Disease (CVD-f) and Self-perceived Health - Maracanaú, CE, Brazil, 2012

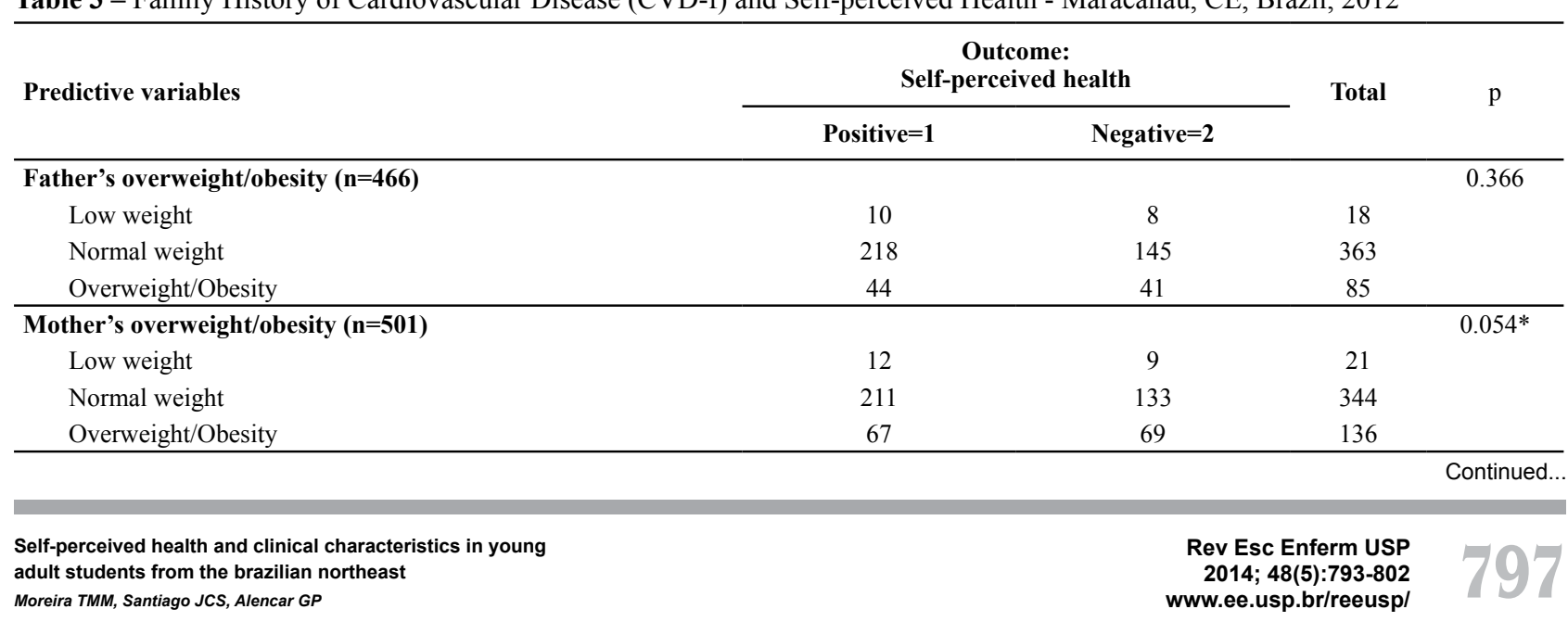


Outcome:

Self-perceived health

Predictive variables

Positive $=1 \quad$ Negative $=2$

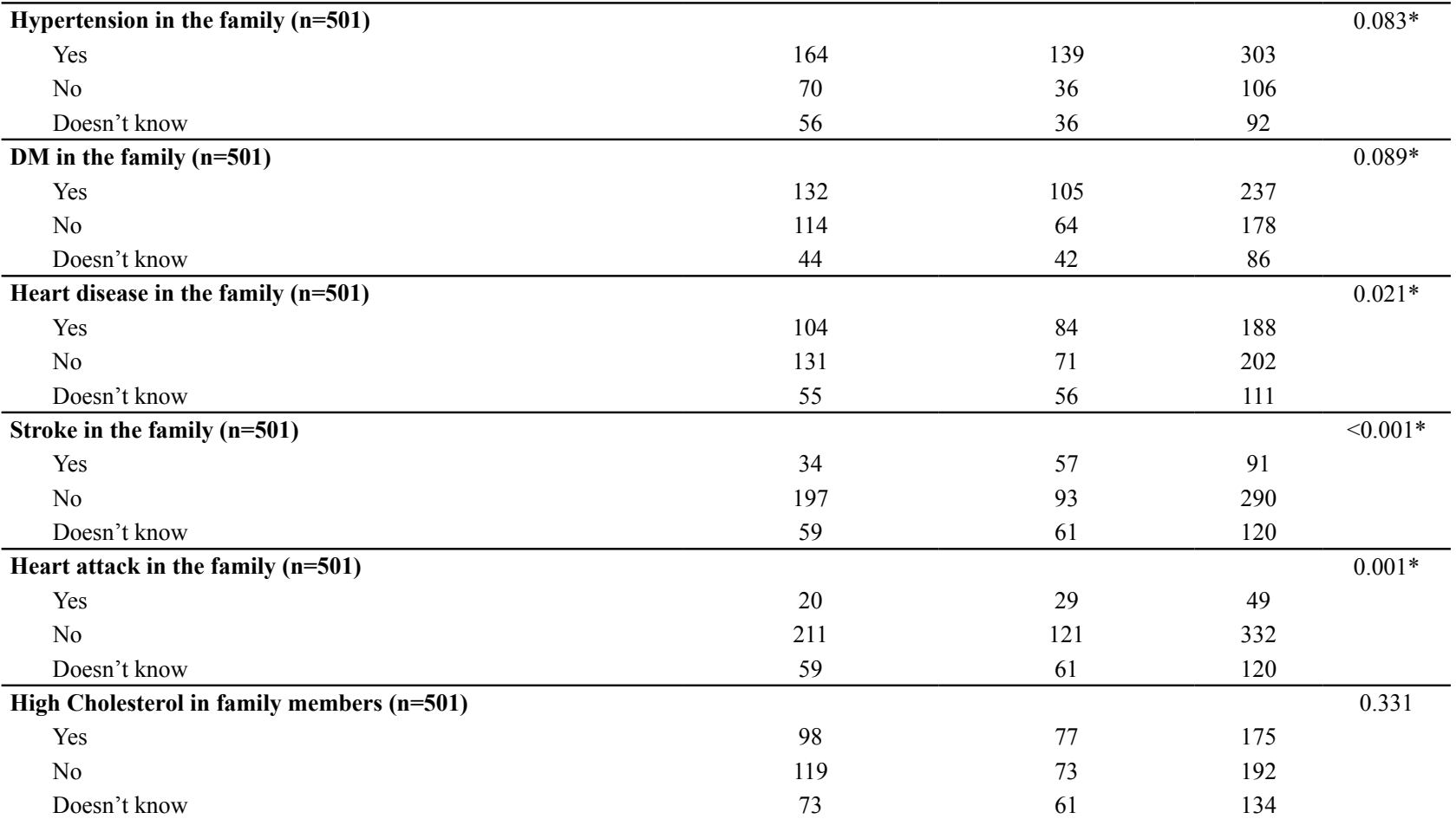

In Table 4, we will present the Clinical Characteristics Observed (CC-O).

( $p \leq 0.2$ ) with Self-perceived health variables: Waist circumference ( $p=0.088$ in women and 0,104 in men), systolic blood pressure $(p=0.092)$ and body mass index $-\operatorname{IMC}(p=0.002)$.

In Table 4, we found a positive statistical association

Table 4 - Clinical Characteristics Observed (CC-o) and Self-perceived Health - Maracanaú, CE, Brazil, 2012

\begin{tabular}{|c|c|c|c|c|}
\hline \multirow[t]{2}{*}{ Predictive variables } & \multicolumn{2}{|c|}{$\begin{array}{c}\text { Outcome: } \\
\text { Self-perceived health }\end{array}$} & \multirow[t]{2}{*}{ Total } & \multirow[t]{2}{*}{$\mathbf{P}$} \\
\hline & Positive $=1$ & Negative $=2$ & & \\
\hline Glycemia $(n=501)$ & & & & 0.936 \\
\hline Normal & 280 & 204 & 484 & \\
\hline Altered & 10 & 7 & 17 & \\
\hline \multicolumn{5}{|l|}{ Abdominal circumference-AC } \\
\hline Female $(n=255)$ & & & & $0.088 *$ \\
\hline Normal & 105 & 98 & 203 & \\
\hline Altered & 20 & 32 & 52 & \\
\hline Male $(n=244)$ & & & & $0.104 *$ \\
\hline Normal & 157 & 74 & 231 & \\
\hline Altered & 6 & 7 & 13 & \\
\hline Systolic blood pressure-SBP $(n=501)$ & & & & $0.092 *$ \\
\hline Normal & 275 & 192 & 467 & \\
\hline Altered & 15 & 19 & 34 & \\
\hline Diastolic blood pressure-DBP $(n=501)$ & & & & 0.585 \\
\hline Normal & 270 & 199 & 469 & \\
\hline Altered & 20 & 12 & 32 & \\
\hline
\end{tabular}




\begin{tabular}{lccc}
\hline \multirow{2}{*}{ Predictive variables } & \multicolumn{3}{c}{$\begin{array}{c}\text { Outcome: } \\
\text { Self-perceived health }\end{array}$} \\
\cline { 2 - 3 } BMI (n=501) & Positive=1 & Negative=2 & \multirow{2}{*}{ Total } \\
Low weight & 12 & 16 & 28 \\
Normal & 189 & 105 & 294 \\
Overweight/Obesity & 89 & 90 & 179 \\
\hline
\end{tabular}

Considering the variables that showed statistical significance when crosstab with the Self-perceived Health,

we built and tested in logistic regression models with binary blocks of variables.

Table 5 - Self-perceived Health and intervening variables - Maracanaú, CE, Brazil, 2012

\begin{tabular}{|c|c|c|c|c|}
\hline & Variables & $\mathbf{p}$ & Odds adjusted & $95 \% \mathrm{CI}$ \\
\hline Block 1 & Male & $0.000^{*}$ & 0.478 & {$[0.327-0.697]$} \\
\hline \multirow[t]{3}{*}{ SES } & Marital status: single. widow or separated & 0.108 & 0.680 & [0.424 -1.089] \\
\hline & Children & 0.886 & 0.966 & {$[0.599-1.556]$} \\
\hline & Live in slums & $0.024 *$ & 2.190 & {$[1.111-4.314]$} \\
\hline Block 2 & Hypertension yes & 0.862 & 0.824 & {$[0.092-7.352]$} \\
\hline \multirow[t]{12}{*}{$\mathrm{CCr}$} & Hypertension no & 0.288 & 0.756 & {$[0.452-1.266]$} \\
\hline & Hypertension doesn't know & 0.568 & & \\
\hline & Diabetes yes & 0.233 & 0.181 & {$[0.011-3.010]$} \\
\hline & Diabetes no & 0.276 & 0.758 & {$[0.461-1.247]$} \\
\hline & Diabetes doesn't know & 0.310 & & \\
\hline & Health care professional says you have hypertension & 0.426 & 2.237 & {$[0.308-16.235]$} \\
\hline & Health care professional says you have dyslipidemia & 0.450 & 1.837 & {$[0.380-8.888]$} \\
\hline & Health care professional says you have hyperglycemia/diabetes & 0.145 & 3.424 & {$[0.654-17.924]$} \\
\hline & Health care professional says you are overweight/obese & 0.236 & 1.520 & {$[0.760-3.038]$} \\
\hline & Lifestyle Excellent and Very Good & $0.006^{*}$ & 2.549 & {$[1.315-4.944]$} \\
\hline & Lifestyle Good & $0.055^{*}$ & 1.597 & {$[0.989-2.580]$} \\
\hline & Lifestyle Regular and Needs Improvement & $0.015^{*}$ & & \\
\hline Block 3 & Obese mother yes & 0.419 & 0.665 & {$[0.247-1.790]$} \\
\hline \multirow[t]{17}{*}{ DCVf } & Obese mother no & 0.143 & 0.729 & {$[0.477-1.113]$} \\
\hline & Obese mother doesn't know & 0.317 & & \\
\hline & Hypertension in the family yes & 0.133 & 1.539 & {$[0.877-2.702]$} \\
\hline & Hypertension in the family no & 0.382 & 1.362 & {$[0.681-2.727]$} \\
\hline & Hypertension in the family doesn't know & 0.319 & & \\
\hline & Heart disease in the family yes & 0.319 & 0.738 & {$[0.417-1.306]$} \\
\hline & Heart disease in the family no & 0.388 & 0.765 & {$[0.417-1.406]$} \\
\hline & Heart disease in the family doesn't know & 0.568 & & \\
\hline & Stroke in the family yes & 0.199 & 1.492 & {$[0.811-2.745]$} \\
\hline & Stroke in the family no & $0.016^{*}$ & 0.518 & {$[0.304-0.883]$} \\
\hline & Stroke in the family doesn't know & $0.000^{*}$ & & \\
\hline & Diabetes in the family yes & 0.698 & 0.896 & {$[0.513-1.564]$} \\
\hline & Diabetes in the family no & 0.766 & 0.912 & {$[0.496-1.677]$} \\
\hline & Diabetes in the family doesn't know & 0.927 & & \\
\hline & Heart attack in the family yes & 0.197 & 1.643 & {$[0.773-3.491]$} \\
\hline & Heart attack in the family no & 0.542 & 0.848 & {$[0.499-1.440]$} \\
\hline & Heart attack in the family doesn't know & 0.155 & & \\
\hline Block 4 & Increased waist circumference & $0.038^{*}$ & 0.536 & {$[0.298-0.966]$} \\
\hline \multirow[t]{4}{*}{ CCo } & Normal systolic blood pressure & 0.186 & 0.616 & {$[0.301-1.262]$} \\
\hline & BMI (Underweight) & 0.234 & 1.658 & {$[0.721-3.811]$} \\
\hline & BMI (Normal) & 0.126 & 0.711 & {$[0.459-1.101]$} \\
\hline & BMI (Overweight/Obesity) & 0.054 & & \\
\hline
\end{tabular}


In Table 5, it is possible to see males ( $<0.001$ ), not living in slums $(p=0.024)$, lifestyle (excellent and very good, good, regular and need improvement), stroke in the family (yes, no and doesn't know) and increased waist circumference and statistically significant in the final model, which explained $83.3 \%$ of the positive health perception, but it was not good to elucidate the negative $(49.4 \%)$, totaling $68.9 \%$ of the explanation of selfperceived health in general.

The Hosmer and Lemeshow measure of overall adjustment indicates no statistically significant difference between the observed and predicted ratings for all models with two or more variables. This value measures the correlation of actual and predicted values of the dependent variable. The best adjust model is indicated by a smaller difference in observed and predicted classification. A good adjust of the model is indicated by a not significant chi-square value ${ }^{(11)}$. In the present case, the Hosmer and Lemeshow chi-square test showed a 9.035, which is not significant $(p=0.339)$.

In multivariate analysis, it is shown the statistical association of Self-perceived health in males $(p<0.001$, adjusted odds of 0.454 and confidence interval ranging from 0.288 to 0.715$)$, not living in slums $(p=0.020$, adjusted odds of 2.611 and confidence interval ranging from 1.164 to 5.856), have a excellent or very good lifestyle $(p<0.048$, adjusted odds of 2.015 and confidence interval ranging from 1.007 to 4.031 ) and not having or doesn't know about cases of stroke in the family ( $p=0.015$, adjusted odds of 0.513 and confidence interval ranging from 0.3 to 0.879 ).

\section{DISCUSSION}

The behavior of individuals can create risks or benefits to their health. Their choices to act in one way or another seems to be influenced by self-perceived health, that is, by how the individual believes his/her health is.

In the present case, we have seen a positive precedence over self-perceived health $(290,57.9 \%)$ in young adults in relation to a negative perception $(211,42.1 \%)$, which was predominant in males, in school young adults who reported living in slums, in those who have an excellent or very good lifestyle and young adults who do not have or do not know if they have cases of stroke in their families. Many studies have shown that self-perceived health is useful to complement diagnosis and show adherence to certain health treatments, since certain sensations of the patient are not captured in the usual tests ${ }^{(12-13)}$.

Self-perceived health includes aspects of physical, cognitive and emotional health ${ }^{(14)}$. Moreover, it is considered an indicator of mortality, i.e, people who report their health as being poor show greater risk of mortality from all causes compared to those who report having excellent health $^{(15)}$. A Canadian study showed that physical conditions were strongly related to perceived health ${ }^{(16)}$. Thus, we see that self-perceived health is strongly related with the actual state or objective health of people and can be seen as a representation of objective health assessments.

Regarding the male gender, Brazilian health policy for men's health proposed in 2009, in order to remedy a historical gap in which they did not receive attention due to the health system. This may have contributed to present more positive perception of health than females. Moreover, in the age group under study, we did not see many health problems, which intensifies this concept. At older ages (>60 years old), it appears that the chances of negative self-perceived health is greater in women than in men $^{(6)}$, demonstrating that the conditions of perceived health remain the same over the years. A study showed that men perceive their health less badly than women, which also affects their use of health services ${ }^{(17)}$.

Not living in a community (slum) was associated with good perceived health. There may be relation with the small percentage of people who said they live there, which may result from inhibition to claim living in a needy place or dissonance in the conception of what is a community of this nature, therefore, and based on the incomes mentioned, this percentage may be higher.

A study that assessed self-perceived health with users of primary health care found that self-perceived health was more positive in subjects of middle-high social class, i.e, living in regions called rich $^{(18)}$. This could be due to higher expectation of the meaning of good health to the highest social classes, directly influenced by the lower prevalence and incidence of disease in these social segments ${ }^{(6,12)}$.

Regarding lifestyle, we refer to inadequate lifestyles as the main cause of death worldwide ${ }^{(19)}$. Lifestyle comprises a multifaceted variable whose outcome is derived from multiple causes related to health of the individual. A multifactorial concept of health problems is due to the theoretical and methodological development of the twentieth century Epidemiology ${ }^{(20-21)}$, but it sets up a challenge to the analysis of health research. It is claimed that the study of disease burden in Brazil is a complex problem and requires targeted actions, without which there will not be resoluteness of health problems ${ }^{(5)}$.

This study showed an association between excellent or very good lifestyle with positive self-perceived health, supporting the assertion that self-perceived health objectively reflect the real health condition of the individual. In contrast, one study found that individuals with health risks factors such as smoking and sedentary lifestyle, and the presence of already established chronic diseases, considered their health positively, indicating controversy between actual health status of the patient and their selfperception $^{(17)}$. A Polish study showed that older people more frequently reported their health as poor and very poor when compared to those under 25 years old ${ }^{(22)}$.
Self-perceived health and clinical characteristics in young adult students from the brazilian northeast Moreira TMM, Santiago JCS, Alencar GP 
The use of the self-perceived health to explain the health-disease process depends on its subjective characteristics, in which also fall within its limitations. In addition, it is influenced by factors such as culture, expectations, worldview and personality of individuals, however, it may be an easy questioning, that can be used both in research and in clinical care practice at different times to monitor progress of patients' health ${ }^{(17)}$.

In a near future, the actions of health promotion of health professionals can focus on preventive approaches with young adults, optimizing health perception and lifestyle, preventing the development of chronicity in later stages of life ${ }^{(5,21-23)}$.

\section{CONCLUSION}

Self-perception of health, because it is configured as a self-declared vote of a person on his/her health, after his/her knowledge, can be used to guide the actions of health promotion to be developed with the clientele of young adults, who, in their great majority, are still not affected by disease, but that has a genetic predisposition for developing chronic diseases and sometimes evidence already points to an unhealthy state, as in the presence of personal risk factors, family and clinical characteristics observed, such as increased waist circumference, overweight/obesity, among others.

In this study, positive health self-perception was influenced by gender, place of residence, lifestyle and knowledge of stroke cases in the family.

It is concluded that, based on the analysis, we found that the perception of health as well as the description of the lifestyle of the patient was often optimistic, being necessary to identify the devices to be worked to bring such perception of the actual condition of a person's health, increasing the effectiveness of health promotion activities undertaken by professionals.

\section{REFERENCES}

1. Azevedo $F R$, Brito $B C$. Influência das variáveis nutricionais e da obesidade sobre a saúde e o metabolismo. Rev Assoc Med Bras [Internet]. 2012 [citado 2014 mar. 05];58(6):71423. Disponível em: http://www.scielo.br/pdf/ramb/v58n6/ v58n6a18.pdf

2. Santos ZMSA. Hipertensão arterial: um problema de saúde pública. Rev Bras Promoção Saúde. 2011;24(4):285-6.

3. Gomes EB, Moreira TMM, Pereira HCV, Sales IB, Lima FET, Freitas Consuelo $\mathrm{HA}$, et al. Fatores de risco cardiovascular em adultos jovens de um município do Nordeste brasileiro. Rev Bras Enferm [Internet]. 2012 [citado 2014 mar. 05];65(4):594600. Disponível em: http://www.scielo.br/pdf/reben/v65n4/ a07v65n4.pdf

4. Galvão NI, Vilela RFJTJ, Orlandi BMM, Ferraz RF, Costa FAA, Fagundes DJ. Determinação do risco cardiovascular em população de check-up espontâneo através do escore de Framingham. Rev Bras Cardiol. 2013;26(5):356-63.

5. Organização Mundial da Saúde; Organização Pan-Americana da Saúde. Doenças crônicas não transmissíveis: estratégias de controle e desafios para os sistemas de saúde. Brasília: Ministério da Saúde; 2011.

6. Reichert FF, Loch MR, Capilheira MF. Autopercepção de saúde em adolescentes, adultos e idosos. Ciênc Saúde Coletiva [Internet]. 2012 [citado 2011 mar. 05];17(12):3353-62. Disponível em: http://www.scielo.br/pdf/csc/v17n12/20.pdf

7. Instituto Brasileiro de Geografia e Estatística. IBGE Cidades. Fortaleza, CE. População [Internet]. Rio de Janeiro; 2010 [citado 2014 mar. 01]. Disponível em: http://www.cidades.ibge.gov.br
8. Hulley SB, Cummings SR, Browner WS, Grady DG, Newman TB. Delineando a pesquisa clínica: uma abordagem epidemiológica. 3a ed. Porto Alegre: Artmed; 2008.

9. Sociedade Brasileira de Cardiologia; Sociedade Brasileira de Hipertensão; Sociedade Brasileira de Nefrologia. VI Diretrizes Brasileiras de Hipertensão. Arq Bras Cardiol 2010;95(1 Supl.1):1-51.

10. Brasil. Ministério da Saúde; Conselho Nacional de Saúde. Resolução n. 466, de 12 de dezembro de 2012. Dispõe sobre as diretrizes e normas regulamentadoras de pesquisas envolvendo seres humanos [Internet]. Brasília; 2012 [citado 2013 nov. 12]. Disponível em: http://conselho.saude.gov.br/ resolucoes/2012/Reso466.pdf

11. Field A. Descobrindo a estatística usando o SPSS. 2a ed. Porto Alegre: Atmed; 2008.

12. Rodrigues CG, Maia A. Como a posição social influencia a autoavaliação do estado de saúde? Uma análise comparativa entre 1998 e 2003. Cad Saúde Pública 2010;26(4):762-74.

13. Faria EC, Silva SA, Farias KRA, Cintra A. Cognitive evaluation of elderly people referenced at the family health strategy in a city in Southern Minas Gerais: municipio del Sur de Minas Gerais. Rev Esc Enferm USP [Internet]. 2011 [cited 2014 Mar 05];45(n.spe2):1748-52. Available from: http://www.scielo. br/pdf/reeusp/v45nspe2/en_19.pdf

14. Nunes APN, Barreto SM, Gonçalves LG. Relações sociais e autopercepção da saúde: projeto envelhecimento e saúde. Rev Bras Epidemiol. 2012;15(2):415-28. 
15. Carvalho FF, Santos JN, Souza LM, Souza NRM. Análise da percepção do estado de saúde dos idosos da região metropolitana de Belo Horizonte. Rev Bras Geriatr Gerontol. 2012;15(2):285-94.

16. Shields $M$, Shooshtari S. Determinants of self-perceived health. Health Rep. 2001;13(1):35-52.

17. Theme Filha MM, Szwarcwald CL, Souza Junior PR. Measurements of reported morbidity and interrelationships with health dimensions. Rev Saúde Pública. 2008;42(1):73-81.

18. Agostinho $M$, Oliveira $M$, Pinto $M$, Balardin $G$, Harzheim E. Autopercepção de saúde entre usuários da Atenção Primária em Porto Alegre, RS. Rev Bras Med Fam Comum. 2010;5(17):9-15.

19. Añez CRR, Reis RS, Petroski EL. Versão brasileira do questionário "Estilo de Vida Fantástico": tradução e validação para adultos jovens. Arq Bras Cardiol. 2008;91(2):102-109.
20. Medeiros ARP, Larocca LM, Chaves MMN, Meier MJ, Wall ML. Epidemiology as a theoretical-methodological framework in the nurses' working process. Rev Esc Enferm USP [Internet]. 2012 [cited 2014 Mar 05];46(6):1519-23. Available from: http://www.scielo.br/pdf/reeusp/v46n6/en_32.pdf

21. Brasil. Ministério da Saúde; Secretaria de Vigilância em Saúde, Departamento de Análise de Situação de Saúde. Plano de ações estratégicas para o enfrentamento das doenças crônicas não transmissíveis (DCNT) no Brasil 2011-2022. Brasília; 2011.

22. Kaleta D, Polańska K, Dziankowska-Zaborszczyk E, Hanke W, Drygas W. Factors influencing self-perception of health status. Cent Eur J Public Health. 2009;17(3):122-7.

23. Luna RL. Hipertensão arterial: diagnóstico e tratamento. Rio de Janeiro: Revinter; 2009. 